\title{
In vitro Efficacy of Biocontrol Agents against Pythium aphanidermatum (Edson) Fitz
}

\author{
P. Naveena ${ }^{1 *}$, V. Prasanna Kumari ${ }^{1}$, P. Anil Kumar ${ }^{1}$ and C. Sandhya Rani ${ }^{2}$ \\ ${ }^{1}$ Department of Plant Pathology, ${ }^{2}$ Department of Entomology, Agricultural college, \\ Bapatla - 522 101, Andhra Pradesh, India \\ *Corresponding author
}

\section{A B S T R A C T}

\section{Keywords}

Pythium

aphanidermatum,

Biocontrol agents,

Antifungal activity

Article Info

Accepted:

20 July 2020

Available Online:

10 August 2020
Present experiment was conducted to evaluate the antifungal efficacy of different biocontrol agents against Pythium aphanidermatum. The six isolates of Trichoderma viz., Trichoderma isolate1, Trichoderma isolate 2, Trichoderma isolate 3, Trichoderma isolate 4, Trichoderma isolate 5 and Trichoderma isolate 6 were studied for their antagonistic nature against $P$. aphanidermatum in vitrousing dual culture method. It was observed that all the Trichoderma isolates acted as antagonists and significantly reduced the mycelial growth of the pathogen $(3.10$ to $4.6 \mathrm{~cm})$ over control $(9.00 \mathrm{~cm})$.

\section{Introduction}

Pythiumspp. are commonly referred to as water moulds that belongs to the kingdom Chromista, phylum Oomycota, class oomycetes, subclass Peronosporomycetidae and family Pythiaceae (Kirk et al., 2008). They naturally exist in soil and water as saprophytes and infect the hypocotyl of seedlings where they live as parasites. Among the Pythium spp. Pythium aphanidermatum (Edson) Fitz. iscosmopolitan in distribution and very common causing damping off in nurseries which is a major constraint in tomato production causing 62 per cent mortality of seedlings (Ramamoorthy et al., 2002).
The most common method to check damping off in nursery beds is the use of fungicides, but frequent and indiscriminate uses of fungicides often leads to environmental pollution and development of resistance in pathogens (Shanmugam and Varma, 1999).

\section{Materials and Methods}

Six isolates of Trichoderma were isolated from the rhizosphere soils of tomato seedlings.

The antagonistic potential of the biocontrol agents was tested against $P$. aphanidermatum by using dual culture technique (Dennis and Webster, 1971). 


\section{Isolation of the pathogen}

The fungus $P$. aphanidermatum was isolated from the collar region of the infected plants showing damping-off symptoms using tissue segment method and purified by single hyphal tip method (Rangaswami, 1958). Small diseased tissues from infected collar region (3 $\mathrm{mm}$ ) along with some healthy tissue were cut with sterile scalpel. The samples were surface sterilized with $0.1 \%$ mercuric chloride solution for $30 \mathrm{sec}$. The diseased samples were subsequently washed in three changes of sterile distilled water to eliminate mercuric ions. The surface sterilized plant samples were transferred onto PDA medium in Petri dishes and incubated at $25 \pm 1{ }^{\circ} \mathrm{C}$ in inverted position to avoid contamination and growth was observed periodically.

\section{Isolation of fungal biocontrol agents}

Fungal antagonists were isolated by following serial dilution technique (Johnson and Curl, 1977). Soil samples were collected from the rhizosphere of tomato seedlings and were shade dried prior to use. $1 \mathrm{~g}$ of soil was suspended in $9 \mathrm{ml}$ of sterile water blank to make a suspension. Serial dilutions $10^{-2}$ to $10^{-}$ ${ }^{7}$ were made by pipetting $1 \mathrm{ml}$ into additional $9 \mathrm{ml}$ water blanks. Finally $1 \mathrm{ml}$ aliquot of desired dilution was added to molten and lukewarm medium and poured into sterilized Petri plates. Plates were rotated gently on the laminar air flow bench to get uniform distribution of soil suspension in the medium. Then the plates were incubated in an inverted position at $25 \pm 1^{\circ} \mathrm{C}$ and observed for desired colonies. For enumeration of fungi, $10^{-3}$ dilution of spore suspension was taken for isolation. Isolation of fungal antagonists was specifically done on Trichoderma selective medium with three day old colonies of fungal antagonists i.e., Trichoderma which were picked up and purified by single spore method.
All the treatments were replicated four times and incubated at $25 \pm 1{ }^{\circ} \mathrm{C}$. Observations were recorded pertaining to colony diameter and the per cent inhibition of the pathogen over control was calculated by adopting the formula as suggested by Vincent (1927).

Per cent inhibition $(\mathrm{I} \%)=\frac{\mathrm{C}-\mathrm{T}}{\mathrm{C}}$

$\mathrm{I}=$ Per cent inhibition in mycelial growth

$\mathrm{C}=$ Growth of pathogen in control plates

$\mathrm{T}=$ Growth of pathogen in treatment plates

\section{Dual culture technique}

Twenty ml of autoclaved PDA was poured aseptically in to $9 \mathrm{~cm}$ sterile Petri plates and 2 $\mathrm{mm}$ mycelial discs were cut from the edge of actively growing three day old culture of the pathogen and of the fungal antagonist with the help of sterilized cork borer and placed at the periphery at about $1 \mathrm{~cm}$ from the edge of the Petri plate opposite to one another. Pathogen without antagonist served as control.

\section{Results and Discussion}

\section{In vitro efficacy of Trichoderma isolates on $P$. aphanidermatum}

The six isolates of Trichoderma viz., Trichoderma isolate 1, Trichoderma isolate 2, Trichoderma isolate 3, Trichoderma isolate 4, Trichoderma isolate 5 and Trichoderma isolate6 were studied for their antagonistic nature against $P$. aphanidermatum in vitro using dual culture method.

It was observed that all the Trichoderma isolates acted as antagonists and significantly reduced the mycelial growth of the pathogen (3.10 to $4.6 \mathrm{~cm})$ over control $(9.00 \mathrm{~cm})$ (Table 1 and Plate 1) (Fig. 1-3). 
Among the different isolates, isolate 3 was found significantly superior over other isolates with the highest inhibition per cent $(65.56 \%)$ with a minimum radial growth $(3.35 \mathrm{~cm})$ and was followed by isolate 6 (61.67) and isolate 1 (60.00) which were on par with each other. Isolate 2 was slow growing and showed least inhibition of test pathogen Pythium which had overgrown the Trichoderma, though isolate 4 was fast in in its mycelial growth but it failed to inhibit pathogen and was overgrown by the Pythium.
Rest of the isolates had grown fast and showed lysis at the point of interaction and inhibited the growth of pathogen mycelium (Fig. 3).

The present results are in accordance with reports of Rattan et al., (2017) who reported inhibition of Pythium spp. by T. koningii $(51.13 \%), \quad$ T. harzianum $(47.8 \%)$ and $T$. longibrachiatum (35.56\%), T. Viride and T. hamatum (44.94\%).

Table.1 Efficacy of fungal antagonists against $P$. Aphanidermatum

\begin{tabular}{|c|c|c|c|}
\hline S.No. & $\begin{array}{c}\text { Trichoderma as fungal } \\
\text { biocontrol agent }\end{array}$ & $\begin{array}{c}\text { *Mean Radial Growth } \\
(\mathbf{c m})\end{array}$ & $\begin{array}{c}\text { Inhibition } \\
(\mathbf{\%})\end{array}$ \\
\hline $\mathbf{1}$ & Isolate1 & 3.60 & 60.00 \\
\hline $\mathbf{2}$ & Isolate2 & 4.60 & 48.89 \\
\hline $\mathbf{3}$ & Isolate3 & 3.10 & 65.56 \\
\hline $\mathbf{4}$ & Isolate4 & 3.92 & 56.39 \\
\hline $\mathbf{5}$ & Isolate5 & 3.62 & 59.72 \\
\hline $\mathbf{6}$ & Isolate6 & 3.45 & 61.67 \\
\hline $\mathbf{7}$ & Control & 9.00 & - \\
\hline & SEm \pm & $\mathbf{0 . 0 6 2}$ & - \\
\hline & C.D. (0.05\%) & $\mathbf{0 . 1 8 4}$ & - \\
\hline & CV\% & $\mathbf{2 . 7 8 2}$ & - \\
\hline
\end{tabular}

* Mean of four replications

Fig.1 Lysis of pathogen Mycelium at the point of interaction; Fig.2 Microbial interactions of Trichoderma with $P$. aphanidermatum

Fig.1

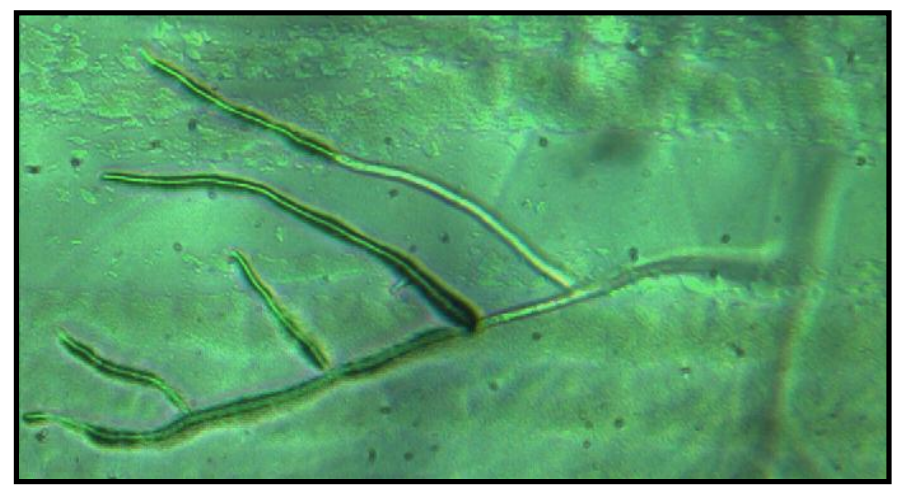

Fig. 2

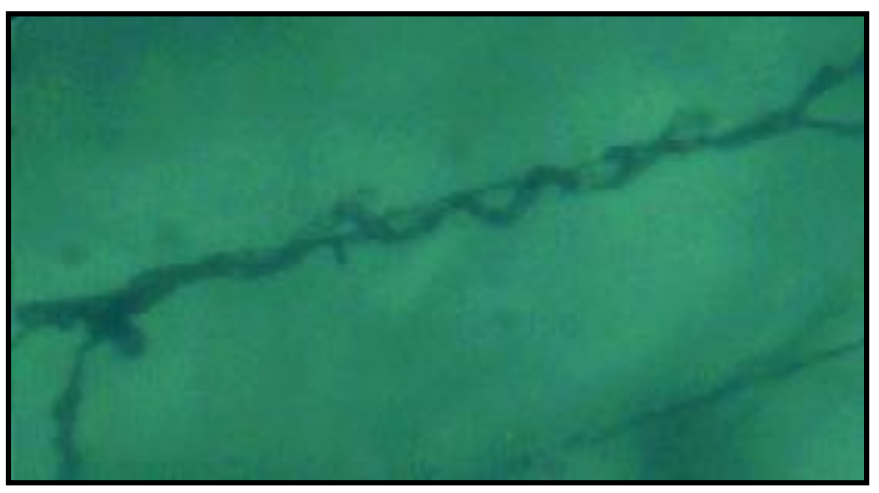


Fig.3 Inhibition in the growth of $P$. aphanidermatum dual cultured with Tricoderma strains

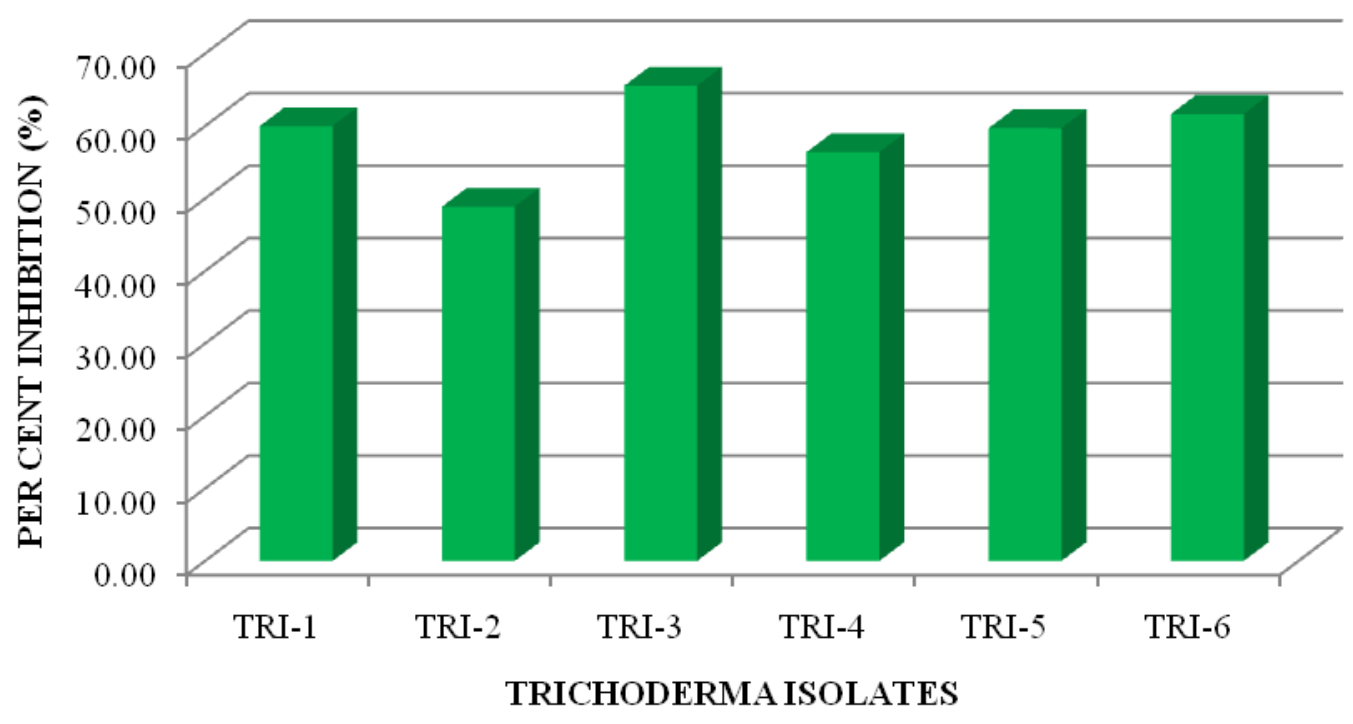

Plate.1 In vitro efficacy of Trichoderma isolates against $P$. aphanidermatum by dual cultue method

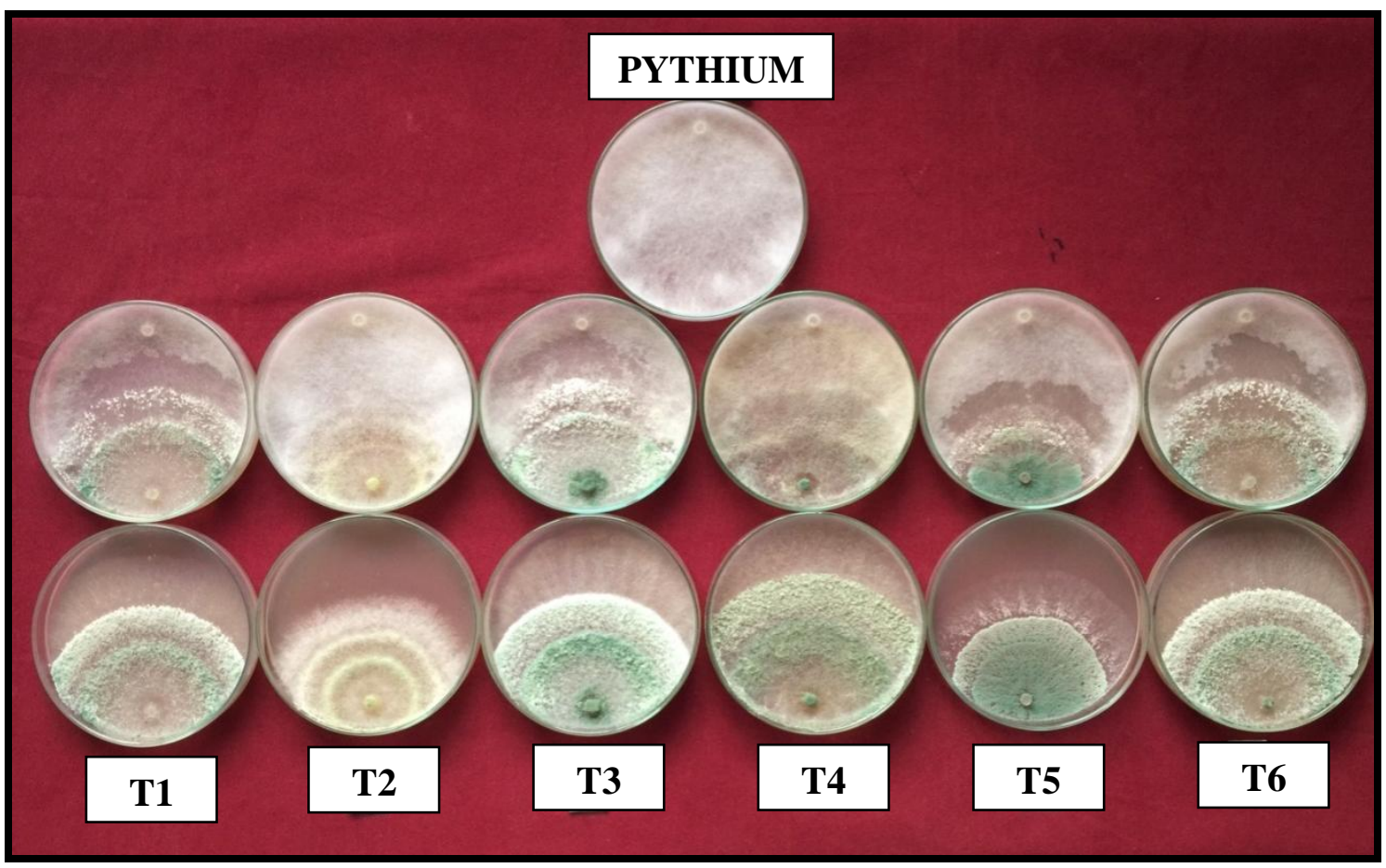

Thakur et al., (2017) also reportedfungal hamatum (44.94\%) over Pythium and inhibition by $T$. Harzianum $(50.28 \%)$ and $T$. Fusarium sp. causing ginger rhizome rot. In 
vitro experiments conducted by Muthukumar et al., (2011) with eight Trichoderma isolates from chilli rhizosphere showed that $\mathrm{TVC}_{3}$ isolate recorded maximum growth inhibition on mycelial growth of $P$. aphanidermatum (88.0\%) compared with control, followed by $\mathrm{THC}_{1}(83.9 \%)$ and $\mathrm{TVC}_{5}(80.0 \%)$.

Muthukumar et al., (2010) studies also reported highest mycelial growth inhibition of $P$. Aphanidermatum with the combination of $T$. viride $+P$. fluorescens + Zimmu leaf extract.

Microbial interactions of Trichodermaisolate 3 also showed antagonistic with the pathogen (Fig. 2).

Neelamegan (2004) also evaluated Trichoderma isolates viz.T. viride, $T$. harzianum and Laetisaria for the antagonistic activity against $P$. indicumin vitro.Among them, $T$. viride was highly inhibitory to $P$. indicum. Volatile andnon-volatile antibiotics of $T$. viride significantly inhibited the growth of $P$. indicum in vitro.

Ten strains of Trichoderma species were screened against $P$. aphanidermatum by dual culture method. Efficacy of culture filtrates ofthe strains was also determined.

Since mycoparasitism plays importantrole in antagonism mechanism of Trichoderma spp., extracellularenzymatic activity of the strains was assayed. Among the strains tested, $T$. viride 1433 was found most effective against P. aphanidermatum (Vinit Kumar Mishra, 2010).

In conclusion, it was observed that among the different isolates tested, isolate 3 was found significantly superior over other isolates with the highest inhibition per cent $(65.56 \%)$ and with a minimum radial growth.

\section{References}

Dennis C and Webster J 1971 Antagonistic properties of species-groups of Trichoderma. I. Production of nonvolatile antibiotics. Transactions of the British Mycological Society, 57: 2539.

Johnson LF and Curl EA 1977 Methods for research on the ecology of soil borne plant pathogens. Burgess Publishing Company Minneapolis, Pp. 27-35.

Kirk P, Cannon PF, Minter D W and Stalpers JA 2008 Ainsworth \& Bisby's Dictionary of the Fungi. 10th edition. CAB International, Wallingford, UK.

Muthukumar A Eswaran A and Sangeeta G 2010Occurance, virulence and pathogenicity of species of Pythium inciting damping-off disease in chilli. Journal of Mycology and Plant Pathology, 40(1): 67-71.

Muthukumar A, Eswaran A and Sanjeevkumar K 2011 Exploitation of Trichoderma Species on the growth of Pythium aphanidermatum.Brazilian Journal of Microbiology, 42: 15981607.

Neelamegam R 2004 Evaluation of fungal antagonists to control damping-off of tomato Lycopersicon esculentum Mill. caused by Pythium ultimum. Journal of Biological Control, 18:97-102.

Ramamoorthy V, Raghuchander $\mathrm{T}$ and Samiyappan R 2002 Enhancing resistant of tomato and hot pepper to Pythium disease by seed treatment with Fluorescent pseudomonads. European Journal of Plant Pathology, 108: 429441.

Rangaswami G 1958 An agar blocks technique for isolating soil microorganisms with special reference to Pythiaceous fungi. Science Culture, 24: 85.

Rattan V, Mishra A, Singh R, Tomar A, 
Trivedi S and Dixit S 2017 In vitro evaluation of chemical fungicides and bioagents against Pythium aphanidermatum. Journal of Natural Resource andDevelopment, 12 (1): 1114.

Shanmugam V and Varma AS 1999 Effect of native antagonists against Pythium aphanidermatum, the causal organism of rhizome rot of ginger. Journal of Mycology and Plant Pathology, 29 (3): 375-379.
Thakur A, Thakur N and Dohroo N P 2017 Rhizome rot of ginger-management through non-chemical approach. International Journal of Plant Protection, 10 (1): 140-145.

Vincent J M 1927 Distribution of fungal hyphae in the presence of certain inhibitors. Nature, 159: 850.

Vinit Kumar Mishra 2010 In Vitro Antagonism of Trichoderma Species against Pythium aphanidermatum. Journal of Phytology, 2(9): 28-35.

\section{How to cite this article:}

Naveena, P., V. Prasanna Kumari, P. Anil Kumar and Sandhya Rani, C. 2020. In vitro Efficacy of Biocontrol Agents against Pythium aphanidermatum (Edson) Fitz. Int.J.Curr.Microbiol.App.Sci. 9(08): 2376-2381. doi: https://doi.org/10.20546/ijcmas.2020.908.272 